\title{
Genetic potential and traits association in desi and kabuli chickpea genotypes
}

\author{
Quaid Hussain*, Rozina Gul, Nazir Ahmad, Tariq Aziz, Imran Khan and \\ Rashid Mabood
}

Department of Plant Breeding and Genetics, Faculty of Crop Production Sciences, University of Agriculture,

Peshawar-Pakistan

*Corresponding author's email: quaid_hussain@yahoo.com

Citation

Quaid Hussain, Rozina Gul, Nazir Ahmad, Tariq Aziz, Imran Khan and Rashid Mabood. Genetic potential and traits association in desi and kabuli chickpea genotypes. Pure and Applied Biology. Vol. 5, Issue 4, pp752-759.

http://dx.doi.org/10.19045/bspab.2016.50094

\begin{tabular}{llll}
\hline \hline Received: 13/02/2016 & Revised: 26/07/2016 & Accepted: 02/08/2016 & Online First: 08/08/2016 \\
\hline \hline
\end{tabular}

\section{Abstract}

The present experiment was carried out at the experimental area, University of Agriculture, Peshawar, Pakistan during the growing season of 2013-14. The current research work was planned to evaluate the genetic potential and traits association in 20 Desi and Kabuli chickpea genotypes (10 Desi and 10 Kabuli). The genetic materials were grown in a randomized complete block design (RCBD) with three replications. Data were collected on plant height $(\mathrm{cm})$, secondary branches plant ${ }^{-}$ 1 , pods plant ${ }^{-1}$, seed yield $\left(\mathrm{kg} \mathrm{ha}^{-1}\right)$, biological yield plot $^{-1}$ and harvest index. Genotypes revealed significant differences for most of the traits which ranged from 63.66 to $105.28 \mathrm{~cm}$ for plant height, 8 to 18 for secondary branches plant ${ }^{-1}, 43$ to 64 for pods plant ${ }^{-1}, 862$ to $2481 \mathrm{~kg}$ for seed yield $\left(\mathrm{kg} \mathrm{ha}^{-1}\right)$, 1383 to $3576 \mathrm{~g}$ for biological yield plot $^{-1}$ and 20 to $39 \%$ for harvest index. Mean squares showed highly significant differences $(\mathrm{P} \leq 0.05)$ for comparative performance of Kabuli and Desi genotypes. Mean value for seed yield $\left(\mathrm{kg} \mathrm{ha}^{-1}\right)$ of Kabuli genotypes was $1210.10 \mathrm{~kg}$, which was comparatively less than mean value of Desi genotypes which was $1823.90 \mathrm{~kg}$. Among Kabuli genotypes, analysis of variance $(\mathrm{P} \leq 0.05)$ showed significant differences for most of the traits. Genotype NKC-5-S14 showed minimum (861.60 $\mathrm{kg} \mathrm{ha}^{-1}$ ) seed yield while maximum (1589.30 kg ha-1) seed yield was recorded for NKC-5-S16. Mean squares in Desi genotypes also revealed significant differences $(\mathrm{P} \leq 0.05)$ for most of the traits. Maximum $\left(2481.3 \mathrm{~kg} \mathrm{ha}^{-1}\right)$ seed yield was given by genotype NIFA2005 , while minimum (1002.90 $\mathrm{kg} \mathrm{ha}^{-1}$ ) seed yield was recorded for genotype SL-3-29. Broad sense heritability estimates for yield and yield components were moderate to high that ranged from $54 \%$ to $92 \%$. Positively and highly significant association of seed yield was observed with biological yield $\operatorname{plot}^{-1}\left(\mathrm{r}=0.85^{* *}\right)$ and harvest index $\left(\mathrm{r}=0.42^{* *}\right)$, while significantly negative correlation was observed with 100 -seed weight $\left(\mathrm{r}=-0.26^{*}\right)$. Biological yield $\operatorname{plot}^{-1}$, harvest index would be the proper choice criteria for better seed yield in chickpea. Results showed that genotypes NIFA-2005, NDC-4-20-5, SL-3-64, NDC-4-20-4 and NKC-5-S16 performed better and could be utilized as a part of future breeding projects for the improvement of high yielding cultivars.

Keywords: Cicer arietinum; Genetic variability; Heritability; Correlation

\section{Introduction}

Chickpea (Cicer arietinum L.), otherwise called bengal gram or garbanzo, is one of the soonest food vegetables developed by man and assumes a key part in human eating routine and agricultural system. It belongs to family Fabaceae and genus Cicer, approximately all Cicer species have 
$2 \mathrm{n}=2 \mathrm{x}=16$ chromosomes. Chickpea kernels contain 25-29\% protein, 38-59\% starch, 5$6 \%$ lubricant, $3 \%$ fiber, $3 \%$ searing trash and $0.3 \%$ phosphorus and $0.2 \%$ calcium [1]. Dhal is the part of chickpea without its seed coat [2]. During 2014-15, the gram, one of the major pulses grown in rainfed areas on marginal lands recorded production of 484 thousand tonnes against the production of 399 thousand tonnes during the same period last year, witnessed a growth of 21.3 percent due to increase in area and favorable weather condition. [3].

Two particular types of chickpea are perceived, i.e. Desi and Kabuli. In Desi chickpea, the regular seed types include different shades and blends of cocoa, yellow, green and dark. The blooms are for the most part pink and the plants show different degrees of anthocyanin pigmentation, although some Desi types have white blossoms and no anthocyanin pigmentation on the stem. The Desi types represent $80-85 \%$ of chickpea zone The Kabuli type chickpeas are described by white shaded seed, slight seed coat, white blooms, smooth seed surface, and absence of anthocyanin pigmentation on the stem. When contrasted with Desi types, the Kabuli types have larger amounts of sucrose and lower levels of fiber. The Kabuli types for the most part have considerable estimated seeds and get higher business cost than Desi sorts [4]. Plant reproducers are constantly trying to enhance the hereditary capability of yield for the harvest to meet the requirements of the developing population. Plant breeders are continuously struggling to improve the genetic potential of yield of this crop so as to meet the demands of the growing population. The approaches to make significant improvement in chickpea production require information on nature and magnitude of genetic variation in quantitative characters and their interrelationship in population comprising diverse genotypes, which are important fundamentals for systematic breeding programme [5]. Keeping in view the most importance of genetic variability, heritability and traits association the present investigation was undertaken on 20 genotypes of chickpea.

\section{Materials and methods}

The experiment on genetic potential and traits association in Desi and Kabuli chickpea genotypes was conducted at the experimental area, University of Agriculture, Peshawar during growing season 2013-14. The experimental material comprises of 10 Desi and 10 Kabuli chickpea genotypes, which were evaluated in the field environments in a randomized complete block design with three replications. The experimental plot involved four rows, each had 4 meter in length. Row to row and plant-to-plant spaces were 30 and $10 \mathrm{~cm}$, respectively. The plot to plot distance was $60 \mathrm{~cm}$.

\section{Statistical analysis}

The information recorded on every parameter was subjected to analysis of variance (ANOVA) procedure suitable for a randomized complete block design through MSTATC PC program. The mean contrasts among chickpea genotypes for distinctive morphological and yield characteristics were measured by applying least significant differences (LSD) test at 5\% level of likelihood as proposed by [6].

Heritability broad sense $\left(\mathrm{h}^{2}{ }_{\text {B.S }}\right)$ was calculated as: $\mathrm{h}^{2}=\mathrm{V}_{\mathrm{g}} / \mathrm{V}_{\mathrm{p}}$.

Correlation

The correlation of seed yield with other yield components was worked out according to [7].

\section{Results and discussion Plant height (cm)}

Statistical analysis stated substantial $(\mathrm{p} \leq 0.01)$ differences among all genotypes for plant height (Table 1). Minimum plant height was observed for genotype SL-3-29 
$(63.66 \mathrm{~cm})$ followed by NKC-10-99 $(76.66$ $\mathrm{cm})$, while genotype NKC-5-S15 recorded maximum $(105.28 \mathrm{~cm})$ plant height followed by NKC-5-S12 $(102.85 \mathrm{~cm})$. Similar results was reported by [8]. Mean square data for plant height discovered highly significant $(p \leq 0.01) \quad$ variances for comparative performance between Kabuli and Desi chickpea genotypes (Table 1). Similar results in comparative performance between Kabuli and Desi chickpea genotypes was observed by [9]. Among Kabuli genotypes,

Table 1. Mean squares Mean squares for plant height (PH), Secondary branches plant ${ }^{-1}$

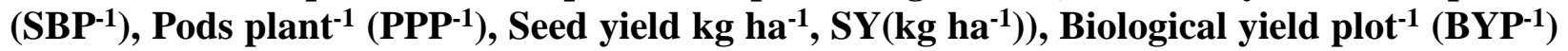
and Harvest index $(\mathrm{HI})$

\begin{tabular}{|c|c|c|c|c|c|c|c|}
\hline S.O.V & df & PH & SBP $^{-1}$ & PPP $^{-1}$ & $\mathbf{S Y}\left(\mathbf{k g ~ h a}^{-\mathbf{1}}\right)$ & $\mathbf{B Y P}^{-1}$ & HI \\
\hline Replication & 2 & 47.83 & 0.67 & 54.46 & 220575 & 521912 & 28.5418 \\
\hline Genotypes & 19 & $226.23^{* *}$ & $17.62^{* *}$ & $135.43^{*}$ & $657383^{* *}$ & $1224241^{* *}$ & $58.1875^{* *}$ \\
\hline Kabuli & 9 & $282.39^{* *}$ & $8.69^{* *}$ & $140.69^{* *}$ & $182176^{* *}$ & $906681^{* *}$ & $35.1809^{*}$ \\
\hline Desi & 9 & $129.95^{* *}$ & $19.76^{* *}$ & $96.98^{*}$ & $577597^{* *}$ & $1226062^{* *}$ & $39.5238^{* *}$ \\
\hline $\begin{array}{c}\text { Kabuli vs } \\
\text { Desi }\end{array}$ & 1 & $587.37^{* *}$ & $78.71^{* *}$ & $434.16^{* *}$ & $5652320^{* *}$ & $4065892^{* *}$ & $433.2202^{* *}$ \\
\hline Error & 38 & 9.28 & 2.21 & 29.71 & 55787 & 134219 & 8.4949 \\
\hline C.V(\%) & & 3.65 & 11.3 & 10.37 & 15.57 & 14.81 & 9.85 \\
\hline
\end{tabular}

Genotypic and phenotypic variances for the plant height were 72.32 and 81.59. High heritability (0.89) was recorded for plant height (Table 2). High heritability for plant height in chickpea genotypes was also reported by [10-12]. Positive and highly significant relationship of plant height was observed with biological yield $\operatorname{plot}^{-1}(\mathrm{r}=$ $0.37 * *)$, while negative and highly

\section{(Table 3)}

Table 2. Genetic, environmental and phenotypic variances with heritability (bs) for various traits of chickpea genotypes.

\begin{tabular}{|c|c|c|c|c|}
\hline Traits & Vg & Ve & Vp & $\mathbf{h}^{2}$ \\
\hline Plant height $(\mathrm{cm})$ & 72.32 & 9.28 & 81.59 & 0.89 \\
\hline Secondary branches plant ${ }^{-1}$ & 5.14 & 2.21 & 7.35 & 0.70 \\
\hline Pods plant $^{-1}$ & 35.24 & 29.71 & 64.95 & 0.54 \\
\hline Seed yield $\left(\mathrm{kg} \mathrm{ha}^{-1}\right)$ & 200532.00 & 55787.00 & 256319.00 & 0.78 \\
\hline Biological yield plot $^{-1}(\mathrm{~g})$ & 363340.67 & 134219.00 & 497559.67 & 0.73 \\
\hline Harvest index (\%) & 16.56 & 8.49 & 25.06 & 0.66 \\
\hline
\end{tabular}

Mean square data regarding secondary branches plant ${ }^{-1}$ manifested outstanding significant $(\mathrm{p} \leq 0.01)$ variances among all genotypes (Table 1). Genotype SL-3-64 mean squares presented highly significant $(\mathrm{p} \leq 0.01)$ variances for this trait. Minimum plant height was recorded for NKC-10-99 $(76.66 \mathrm{~cm})$ and maximum was observed for genotype NKC-5-S15 $(105.28 \mathrm{~cm})$. In Desi genotypes, highly significant $(\mathrm{p} \leq 0.01)$ differences were observed for plant height. Minimum plant height was recorded for genotype SL-3-29 $(63.66 \mathrm{~cm})$ and maximum height was recorded for NDC-4-20-2 (88.76 $\mathrm{cm})$ (Table 4). significant association of this trait was found with harvest index $(\mathrm{r}=-0.59 * *)$. Plant height observed positive and non-significant correlation with secondary branches plant $^{-1}$ $\left(\mathrm{r}=0.01^{\mathrm{ns}}\right)$, pods plant ${ }^{-1}\left(\mathrm{r}=0.24^{\mathrm{ns}}\right)$ and seed yield $\left(r=0.01^{\mathrm{ns}}\right)$. Similar result of negative and highly significant relationship for this trait with harvest index was reported by [13]

branches plant $^{-1}$ followed by NDC-4-20-4 (10.18), while maximum (17.57) secondary branches plant $^{-1}$ was recorded by genotype NKC-5-S20 which was followed by SL-5-42 
(16.38). Similar results, highly significant difference for secondary branches plant ${ }^{-1}$ in chickpea genotypes was observed by $[14$, $15]$. Mean square analysis exhibited highly significant $\quad(p \leq 0.05)$ variances between Kabuli and Desi genotypes for secondary branches plant $^{-1}$ (Table 1). In Kabuli genotypes, statistical analysis presented noteworthy ( $\mathrm{p} \leq 0.01)$ difference for the said trait. Minimum secondary branches plant ${ }^{-1}$ was recorded by NKC-5-S16 (11.19) and maximum number by genotype NKC-5-S20 (17.57). Among Desi genotypes, highly $(p \leq 0.01)$ differences were observed for secondary branches. Least secondary branches was noted by genotype SL-3-64 (8.23) and maximum was recorded for SL-542 (16.38) (Table 4). Genotypic and phenotypic variances for the secondary branches plant ${ }^{-1}$ were 5.14 and 7.35 , with a high heritability of 0.70 , respectively (Table 2). Related results of high heritability for secondary branches plant $^{-1}$ in chickpea genotypes was reported by $[16,14]$. Secondary branches plant $^{-1}$ was found positive and highly significantly associated with pods plant ${ }^{-1}\left(\mathrm{r}=0.42^{* *}\right)$. Negative and significant correlation of this trait was recorded with harvest index $(r=-0.30 *)$. Positively and non-significantly correlation of this trait with plant height $\left(\mathrm{r}=0.01^{\mathrm{ns}}\right)$, while negative and non-significant association of this trait with seed yield $(\mathrm{r}=$ - $\left.0.24^{\mathrm{ns}}\right)$ and biological yield plot $^{-1}(\mathrm{r}=$ $\left.0.09^{\text {ns }}\right)$. Similar results of positive and highly significant association secondary branches plant $^{-1}$ with pods plant ${ }^{-1}$ and harvest index was observed by [17] (Table 3).

\section{Pods plant ${ }^{-1}$}

Statistical analysis showed highly significant $(\mathrm{p} \leq 0.01)$ differences for pods plant ${ }^{-1}$ among chickpea genotypes (Table 1). Minimum pods plant ${ }^{-1}$ was observed by genotype SL3-64 (43.23) followed by NDC-4-20-4 (44.40), while maximum pods was recorded by genotype NKC-5-S15 (64.33) which was followed by NKC-5-S20 (61.90), SL-8-14 (61.10) and NKC-10-99 (60.63). Similar results were noted by $[17,18]$. Analysis of variance for pods plant $^{-1}$ revealed highly significant $(p \leq 0.01)$ variances between Kabuli and Desi genotypes (Table 1). Similar results in comparative performance between Kabuli and Desi chickpea genotypes also observed by [9]. Among Kabuli genotypes, mean square analysis exhibited highly significant $(\mathrm{p} \leq 0.01)$ variances for the said trait. Maximum pods plant $^{-1}$ had taken by genotype NKC-5-S15 (64.33) and minimum by genotype NKC-5S24 (46.10). In Desi genotypes, significant differences were observed for pods plant ${ }^{-1}$. Minimum pods plant ${ }^{-1}$ was recorded by SL3-64 (43.23) and maximum for SL-8-14 (61.10) (Table 4).

Table 3. Correlation between several characters of chickpea genotypes

\begin{tabular}{|l|l|l|l|l|l|l|}
\hline & PH & SB & $\mathbf{P P P}^{-1}$ & SY & $\mathbf{B Y P}^{-1}$ & HI \\
\hline PH & 1 & $0.01^{\mathrm{ns}}$ & $0.24^{\mathrm{ns}}$ & $0.01^{\mathrm{ns}}$ & $0.37^{* *}$ & $-0.59^{* *}$ \\
\hline SB & & 1 & $0.42^{* *}$ & $-0.24^{\mathrm{ns}}$ & $-0.09^{\mathrm{ns}}$ & $-0.30^{*}$ \\
\hline PPP $^{-1}$ & & & 1 & $-0.12^{\mathrm{ns}}$ & $0.07^{\mathrm{ns}}$ & $-0.32^{*}$ \\
\hline SY & & & & 1 & $0.85^{* *}$ & $0.42^{* *}$ \\
\hline BYP & & & & & 1 & $-0.11^{\mathrm{ns}}$ \\
\hline HI & & & & & & 1 \\
\hline
\end{tabular}

Genotypic and phenotypic variance for pods plant $^{-1}$ was 35.24 and 64.95 , with a moderate heritability of 0.54 , respectively (Table 2). Ssimilar results of moderate $h^{2}$ for pods plant $^{-1}$ in chickpea genotypes also stated by $[19,15]$. Positive and highly significant association of pods plant ${ }^{-1}$ was found with secondary branches plant $^{-1}\left(\mathrm{r}=0.69^{* *}\right)$. Negative and significant relationship of this trait was recorded with harvest index $(\mathrm{r}=$ $\left.0.32^{*}\right)$. Pods plant ${ }^{-1}$ was observed positive and non-significant correlation with plant 
height $\left(\mathrm{r}=0.24^{\mathrm{ns}}\right)$ and biological yield plot $^{-1}$ $\left(\mathrm{r}=0.07^{\mathrm{ns}}\right)$, while negative and nonsignificant association of this trait was found with seed yield $\left(\mathrm{r}=-0.12^{\mathrm{ns}}\right)$. Similar results, pods plant $^{-1}$ was positive and significant associated with harvest index [13]. [14] Also observed similar results, positive and highly significant association of pods plant ${ }^{-1}$ with secondary branches plant $^{-1}$ and harvest index (Table 3 ).

\section{Seed yield (kg ha-1)}

Statistical analysis regarding seed yield established highly significant $(\mathrm{p} \leq 0.01)$ variances among all genotypes (Table 1). Genotype NKC-5-S14 was recorded minimum (861.6 kg ha ${ }^{-1}$ ) seed yield, which was followed by NKC-10-99 $\left(869.1 \mathrm{~kg} \mathrm{ha}^{-}\right.$ $\left.{ }^{1}\right)$. However, high seed yield $(2481.3 \mathrm{~kg}$ ha

1) was noted by genotype NIFA-2005 which was followed by NDC-4-20-5 (2297.3 kg ha $\left.{ }^{1}\right)$, SL-3-64 (2065.9 kg ha-1) and NDC-4-20-

Table 4. Mean values

\begin{tabular}{|c|c|c|c|c|c|c|c|}
\hline Group & Genotypes & PH (cm) & SBP-1 $^{-1}$ & SY $\left(\right.$ kgha $\left.^{-1}\right)$ & BYP $^{-1}(\mathrm{~g})$ & HI (\%) & $\mathbf{P P P}^{-1}$ \\
\hline \multirow[t]{11}{*}{ Kabuli } & NKC-10-99 & 76.66 & 13.90 & 869.1 & 1438.7 & 28.88 & 60.63 \\
\hline & NKC-5-S-12 & 102.85 & 12.80 & 1443.7 & 2830.0 & 24.55 & 60.10 \\
\hline & NKC-5-S-14 & 81.85 & 14.28 & 861.6 & 1400.7 & 30.41 & 57.97 \\
\hline & NKC-5-S-24 & 81.19 & 14.14 & 1209.8 & 1961.3 & 29.62 & 46.10 \\
\hline & NKC-5-S-20 & 80.95 & 17.57 & 1434.7 & 2307.3 & 29.65 & 61.90 \\
\hline & NKC-5-S-16 & 88.81 & 11.19 & 1589.3 & 2610.0 & 29.24 & 47.53 \\
\hline & NKC-5-S-17 & 83.38 & 16.04 & 1351.7 & 2672.0 & 24.37 & 46.50 \\
\hline & NKC-5-S-21 & 80.85 & 14.05 & 1141.9 & 2228.7 & 25.17 & 52.20 \\
\hline & NKC-5-S-13 & 84.85 & 14.62 & 1026.0 & 1795.3 & 27.46 & 54.83 \\
\hline & NKC-5-S-15 & 105.28 & 14.57 & 1172.8 & 2894.7 & 19.57 & 64.33 \\
\hline & Mean & 86.67 & 14.32 & 1210.1 & 2213.9 & 26.89 & 55.24 \\
\hline \multirow[t]{13}{*}{ Desi } & NDC-4-20-4 & 79.99 & 10.18 & 2056.7 & 2515.3 & 39.41 & 44.40 \\
\hline & NDC-4-20-2 & 88.76 & 14.85 & 1551.7 & 2526.7 & 29.17 & \\
\hline & NDC-4-20-3 & 79.05 & 9.23 & 1798.0 & 2597.3 & 33.62 & 46.33 \\
\hline & NDC-4-20-5 & 84.95 & 10.42 & 2297.3 & 3346.7 & 32.77 & 48.20 \\
\hline & SL-3-64 & 79.42 & 8.23 & 2065.9 & 3166.7 & 31.48 & 43.23 \\
\hline & SL-5-42 & 83.95 & 16.38 & 1430.9 & 2584.0 & 26.63 & 53.43 \\
\hline & SL-3-15 & 81.90 & 13.76 & 1609.8 & 2358.7 & 32.91 & 45.93 \\
\hline & SL-3-29 & 63.66 & 12.66 & 1002.9 & 1383.3 & 34.93 & 48.27 \\
\hline & SL-8-14 & 81.18 & 12.85 & 1944.8 & 3290.3 & 28.42 & 61.10 \\
\hline & NIFA-2005 & 81.23 & 11.67 & 2481.3 & 3576 & 33.33 & 56.40 \\
\hline & Mean & 80.41 & 12.03 & 1823.9 & 2734.5 & 32.27 & 49.86 \\
\hline & Total mean & 83.54 & 13.17 & 1517 & 2474.2 & 29.58 & 52.55 \\
\hline & LSD & 5.03 & 2.46 & 390.41 & 605.56 & 4.82 & 9.01 \\
\hline
\end{tabular}

4 (2056.7 $\left.\mathrm{kg} \mathrm{ha}^{-1}\right)$. Similar outcomes for seed yield in chickpea genotypes was observed by [20]. Mean data for seed yield showed highly significant $(\mathrm{p} \leq 0.01)$ differences for comparative performance between Kabuli and Desi chickpea genotypes (Table 1). [9] Also observed similar results in comparative performance between Kabuli and Desi chickpea genotypes. Among Desi genotypes, analysis of variance showed highly significant $(p \leq 0.01)$ differences for this said trait. Minimum seed yield was recorded for SL-329 (1002.9 $\left.\mathrm{kg} \mathrm{ha}^{-1}\right)$ and maximum yield for genotype NIFA-2005 (2481.3 kg ha-1). Among Kabuli genotypes, highly significant $(\mathrm{p} \leq 0.01)$ differences were observed for seed yield $\left(\mathrm{kg} \mathrm{ha}^{-1}\right)$. Genotypes NKC-5-S14 was recorded minimum $\left(861.6 \mathrm{~kg} \mathrm{ha}^{-1}\right)$ seed yield and maximum yield was recorded for NKC-5-S16 (1589.3 kg ha'-1) (Table 4). 
Genotypic and phenotypic variances for seed yield were 200532.00 and 256319.00 with high heritability of 0.78 , respectively (Table 2). [21, 20] also reported Similar results of high heritability for this trait in chickpea genotypes. Seed yield displayed positive and highly significant correlation was recorded with biological yield plot $^{-1}(\mathrm{r}$ $\left.=0.85^{* *}\right)$ and harvest index $\left(\mathrm{r}=0.42^{* *}\right)$. Seed yield was observed positively and non-significant association with plant height $\left(\mathrm{r}=0.01^{\mathrm{ns}}\right)$, while negative and nonsignificant association with secondary branches plant $^{-1}\left(\mathrm{r}=-0.24^{\mathrm{ns}}\right)$ and pods plant $^{-1}\left(\mathrm{r}=-0.12^{\mathrm{ns}}\right)$. Positive and highly important relationship of seed yield with biological yield and harvest index also reported by [22] (Table 3).

\section{Biological yield plot $^{-1}(\mathrm{~g})$}

Statistical analysis uncovered massively significant $(\mathrm{p} \leq 0.01)$ variances among chickpea genotypes for biological yield plot $^{-1}$ (Table 1). Least biological yield was observed for genotype SL-3-29 (1383.3 g) followed by NKC-5-S14 (1400.7 g) and NKC-10-99 (1438.7 g), while maximum yield was observed for genotype NIFA2005 (3576.0 g) trailed by NDC-4-20-5 $(3346.7 \mathrm{~g})$ and SL-8-14 (3290.3 g). Related results of highly significant variation for biological yield plot $^{-1}$ in chickpea genotypes also found by [8]. Analysis of variance for biological yield plot $^{-1}$ showed extremely significant $(p \leq 0.01)$ variances for comparative performance among Kabuli and Desi chickpea genotypes. In Desi genotypes, mean data discovered highly important $(p \leq 0.01)$ variances for biological yield plot $^{-1}$. The lowest biological yield plot ${ }^{-1}$ was noted for SL-3-29 (1383.3 g) and maximum yield for genotype NIFA-2005 (3576.0 g). Kabuli genotypes also revealed greatly significant $(\mathrm{p} \leq 0.01)$ differences for biological yield plot $^{-1}$. Genotype NKC-5S14 showed minimum biological yield plot $^{-1}(1400.7 \mathrm{~g})$ while maximum yield was recorded for NKC-5-S15 (2894.7 g) (Table 4).
Genotypic and phenotypic variances for biological yield plot $^{-1}$ were 497559.67 and 134219.00 with high heritability of 0.73 (Table 2). Similar result of high heritability in chickpea genotypes also testified by [12]. Biological yield plot $^{-1}$ showed positive and highly significant association with seed yield $\left(\mathrm{r}=0.85^{* *}\right)$ and plant height $(\mathrm{r}=0.37 * *)$. Positive and non-significant correlation of biological yield plot $^{-1}$ was recorded with pods plant ${ }^{-1}$ $\left(\mathrm{r}=0.07^{\mathrm{ns}}\right)$, while negative and nonsignificant association with harvest index $\left(\mathrm{r}=-0.11^{\mathrm{ns}}\right)$ and auxiliary branches plant ${ }^{-1}$ $\left(r=-0.09^{n s}\right)$. Similar results of positive and highly significant relationship of biological yield plot $^{-1}$ with plant height, while non-significant correlation with harvest index also observed by [22] (Table $3)$.

\section{Harvest Index (\%)}

Mean squares analysis revealed highly significant $(\mathrm{p} \leq 0.01)$ variances for harvest index between all genotypes (Table 1). Minimum harvest index was recorded for genotype NKC-5-S15 (19.57\%) followed by NKC-5-S17 (24.37\%) and NKC-5-S12 $(24.55 \%)$, while maximum harvest index was noticed for genotype NDC-4-20-4 (39.41\%) followed by SL-3-29 (34.93\%), NDC-4-20-3 (33.62\%) and NIFA-2005 $(33.33 \%)$. Similar results for harvest index in chickpea genotypes also stated by [17]. Statistical analysis for harvest index revealed highly significant $(\mathrm{p} \leq 0.01)$ differences for comparative performance among Kabuli and Desi chickpea genotypes. Among Desi genotypes, mean data exhibited highly significant $(\mathrm{p} \leq 0.01)$ variances for the said trait. Minimum harvest index was recorded for SL-5-42 (26.27\%) and maximum value for NDC-420-4 (39.41\%). In Kabuli genotypes, significant $(\mathrm{p} \leq 0.05) \quad$ differences were observed for harvest index. Minimum harvest index was noted for NKC-5-S15 $(19.57 \%)$ and maximum value was recorded for NKC-5-S14 (30.41\%) (Table $4)$. 
Genetic variance for harvest index was 16.56 and phenotypic variance was 25.06 with a high heritability of 0.66 (Table 2). Similar results of high heritability for harvest index in chickpea genotypes was observed by [17, 18]. Positively and high significant relationship of harvest index with seed yield $\left(\mathrm{r}=0.42^{* *}\right)$. Negative and significant association of harvest index was recorded with auxiliary branches plant $^{-1}\left(\mathrm{r}=-0.30^{*}\right)$ and pods plant ${ }^{-1}(\mathrm{r}=$ $\left.0.32^{*}\right)$. Negatively and non-significantly association of this trait with biological yield $\operatorname{plot}^{-1}\left(r=-0.11^{\text {ns }}\right)$. Similar result of positively and highly significantly association of harvest index with plant tallness and pods plant ${ }^{-1}$ also stated by [18] (Table 3).

\section{Conclusions}

For growing high yielding genotypes, NIFA-2005, NDC-4-20-5, SL-3-64, NDC4-20-4 and NKC-5-S16 are prescribed to be the best parents using in cross combinations.

Genotypes NIFA-2005, NDC-4-20-5, SL3-64, NDC-4-20-4, NKC-5-S16, NKC-5S15, NKC-5-S12 and NKC-5-S20 were discovered unrivaled in numerous quantitative attributes and can be utilized for developing high yielding cultivars in future chickpea breeding programs.

\section{Authors' contributions}

Conceived and designed the experiments: Q Hussain, Performed the experiments: Q Hussain \& R Mahbood, Analyzed the data: N Ahmed \& T Aziz, Contributed reagents/ materials/ analysis tools: R Gul \& I Khan, Wrote the paper: Q Hussain.

\section{References}

1. Knights EJ, Acikgoz, Warkentin N, Bejiga GT, Yadav SS \& Sandhu JS (2007). Area, production and distribution. In: Chickpea Breeding and Management, pp. 167-178, (Yadav S, Redden S, Chen R, \& Sharma WB. eds). $\mathrm{CAB}$, Wallingford, UK.

2. Hulse JH (1991). Nature, composition and utilization of grain legumes. In: Uses of tropical Legumes: Proceedings of a Consultants Meeting. 1989, ICRISAT
Center. ICRISAT, Patancheru, A. P. 502 324, India. 11-27.

3. Federal Bureau of Statistics (FBS) (2014-2015). Government of Pakistan, Islamabad.

4. Gaur PM, Tripathi, Gowda S, Rao CLLR, Sharma GV, Pande HC \& Sharma SM (2010). Chickpea Seed Production Manual. Patancheru, Andhra Pradesh, India: ICRISAT

5. Arshad M, Bakhsh A, Zubair M \& Ghafoor A (2003). Genetic variability and correlation studies in chickpea (Cicer arietinum L.). Pak J Bot. 35(4): 605-611.

6. Steel RGD \& Torrie JH (1980). Principles and procedures of statistics, a biological approach, $2^{\text {nd }}$ ed. Mc Graw Hill, Inc. New York, Toronto, London.

7. Kwon SH \& Torrie JH (1964). Heritability and interrelationship among traits of two soybean population. Crop Sci. 4: 194-198

8. Zeeshan M, Arshad W, Ali S, Owais M, Zulkiffal M \& Hussain M (2013). Genetic divergence and character association in chickpea (Cicer arietium) under rainfed conditions. Wudpecker $J$. Agric Res. 2(1): 28-32.

9. Tripathi S, Sridhar V, Jukanti A K, Suresh K, Rao B V, Gowda C L \& Gaur P M

(2012). Genetic variability and interrelationships of phenological, physicochemical and cooking quality traits in chickpea. Plant Genetic Res. 10(3): 194-201.

10. Ali Q, Ahsan M, Khaliq I, Elahi M, Shahbaz M, Ahmad W \& Naees M. 2011. Estimation of genetic association of yield and quality traits in chickpea (Cicer arietinum L.). Int Res J Plant Sci. 2(6): 166-169.

11. Ali Q, Tahir MHN, Sadaqat HA, Arshad S, Farooq J, Ahsan M, Waseem M \&Iqbal M (2011). Genetic variability and correlation analysis for quantitative traits in chickpea genotypes (Cicer arietinum L.). J Bacteriology Res. 3(1): 6-9. 
12. Khan R, Farhatullah \& Khan H (2011). Dissection of genetic variability and heritability estimates of chickpea germplasm for various morphological markers and quantitative traits. Sarhad $J$ Agric. 27(1): 67-72.

13. Azar MR, Javanmard A, Shekari F, Mohammad AP \& Esfandyari E (2013). Evaluation of yield and yield components chickpea (Cicer arietinum L.) in intercropping with spring barley (Hordeum vulgare L.). Cercetari Agronomice in Moldova. 4(156): 75-85.

14. Gul R, Khan H, Bibi M, Ain QU \& Imran B (2013). Genetic analysis and interrelationship of yield attributing traits in chickpea (Cicer arietinum L). J Anim Plant Sci. 23(2): 512-526.

15. Padmavathi PV, Murthy SS, Rao VS \& Ahamed ML (2013). Correlation and path coefficient analysis in Kabuli chickpea (Cicer arietinum L.). Int $J$ Applied Bio Pharm Tech. 4(3): 107-110.

16. Ali Q, Iqbal M, Ahmad A, Tahir MHN, Ahsan M, Javed N \& Farooq J (2013).

Screening of chickpea (Cicer arietinum L.) germplasm against ascochyta blight [Ascochyta rabiei (Pass.) Lab.] Correlation and combining ability analysis for various quantitative traits. $J$ Plant Breed Crop Sci. 5(6): 103-110.

17. Malik SR, Bakhsh A, Asif MA, Iqbal U \& Iqbal SM (2010). Assessment of genetic variability and interrelationship among some agronomic traits in chickpea. Int J Agric Bio. 12(1): 81-85

18. Ramanappa TM, Chandrashekara K \& Nuthan D (2013). Analysis of variability for economically important traits in chickpea (Cicer arietinum L.). Int J Res Applied Nat Soci Sci. (IJRANSS). 1(3): 133-140.

19. Hassan EU, Arshad M, Ahsan M \& Saleem M (2008). Genetic variability and interrelationship for grain yield and its various components in chickpea (Cicer arietinum L.). J Agric Res. 46(2): 109-116

20. Farshadfar E, Mahtabi E, Safavi SM \& Shabani A (2013). Estimation of variability and genetic parameters in chickpea (Cicer arietinum L.) genotypes. Int J Agro Plant Prod. 4 (10): 26122616.

21. Akhtar LH, Pervez MA \& Nasim M (2011). Genetic divergence and interrelationship studies in chickpea (Cicer arietinum L.). Pak J Agri Sci. 48(1): 3539.

22. Shamsi K, Kobraee $\mathrm{S} \&$ Haghparast $\mathrm{R}$ (2010). Drought stress mitigation using supplemental irrigation in rainfed chickpea (Cicer arietinum L.) varieties in Kermanshah, Iran. Afri J Biot. 9(27): 41974203. 